\title{
Determinants of Bear Market Performance at the Nairobi Securities Exchange in Kenya
}

\author{
Ogilo Fredrick
}

School of Business, University of Nairobi, Kenya

Copyright $(\mathcal{C} 2015$ by authors, all rights reserved. Authors agree that this article remains permanently open access under the terms of the Creative Commons Attribution License 4.0 International License

\begin{abstract}
This study sought to establish the determinants of bear market performance by taking a survey of investors at the Nairobi Securities Exchange. To achieve this, a quantitative and qualitative research design was adopted and the study involved administering questionnaires to 500 retail investors participating at the Nairobi Securities Exchange through five purposively selected stock brokerage firms based in Mombasa Town. Convenient sampling technique was used to administer questionnaires to respondents. Data was analyzed by the use of descriptive statistics and correlation analysis was carried out to determine the relationship between the variables. A multiple regression model was employed to analyze the independent variables and their effect on bear market performance. The ANOVA result at a p-level of .05 showed that all the four variables; transaction cost, mobilization of resources by retail investors, financial literacy and cultural values had an influence on bear market performance. The Pearson Moment correlation analysis showed that bear market performance was weakly associated with transaction costs and financial literacy while the relationship between bear market performance and mobilization of resources by retail investors as well as cultural values was largely insignificant. The study recommends that further research should be carried out on the economic cycle and its influence on bear market performance.
\end{abstract}

Keywords Bear Market, Transaction Cost, Mobilization of Resources, Retail Investors, Cultural Values

\section{Introduction}

The concept of bear market can be traced back to the time of Charles Dow when he made an analysis of trends in the Dow Jones Stock Market. The security trend may either be increasing or decreasing. Niederhoffer and Osborne [1] explained the concept of bear market as a situation when the stock prices exhibits a continuous downward trend, the opposite of the bear market is a bull market whereby the stock prices exhibits a continuous increasing trend. Niederhoffer and Osborne [1] noted that the bear market shows three clear cut peaks: Each peak is lower than the previous peak; the bottoms are also lower than the previous bottoms. In vindicating this concept, Robert and Pretcher [2] also in an analysis of Dow Theory noted that there are three principal phases of a bear market. They are: the abandonment of hopes, selling due to decreased business and earnings, and finally, distress selling of sound securities regardless of value.

Richard et al. [3] by basing their argument on technical analysis theory found out that stock market volatility is higher during bear markets. They also provided two possible explanations for the higher volatility during bear markets. First the increased uncertainty and risk observed in the bear market may generate a decline in equity values. Also in the context of increased uncertainty investors react to bad news more quickly, adding then more volatility to the market. Further, Chordia [4] also suggest that the different behavior observed in the stock market liquidity in bear markets may be related with volatility. Thus, bear markets could be subject to falling liquidity.

Ramos [5] found out that bear market corresponds to periods of a generalized downward trend (negative returns). Dukes et al. [6] vindicated this by using the Standard and Poor's 500 index and found out that bear markets are periods in which the index decreased by at least $20 \%$ from a peak to a trough. Chauvet and Potter [7] explained that a stock market moves to a bear state if prices have declined for a substantial period since their previous (local) peak. The bear market is the bull market which is associated with persistently rising share prices, strong investor interest and raised financial well-being.

\section{Determinants of Bear Market}

Lesmond et al. [8] found out that transaction cost represents a limit that must be exceeded before the securities return will reflect new information. Amy et al. [9] found out that the average transaction costs are a function of trade size for each bond traded at the bourse. They further established that transaction costs decrease significantly with 
trade size. Rogers [10] observed that inflation rates as an element of transaction costs erode the spending power of consumers. The author also observed that when inflation rate is high, consumers are not likely to invest in stocks since they will be focusing on spending on consumables first. High inflation rates can therefore lead to depressed share prices for a long time since there will be inadequate disposable income. Durham [11] noted that when central banks make credible commitment to reduce inflation, expectations would adjust accordingly thus leaving disposable income unchanged. But he went on to say that in most cases when the central bank is acting, the effect would have lasted for about three to four months.

Maxx [12] established that consumer financial literacy education promotes increased alienation through encouraging perpetual consumption of financial products and integration into, and reliance upon, the health of the market and the corporations in which individuals invest in. Marten et al. [13] relying on comprehensive measures of financial knowledge, provided evidence of a strong positive association between financial literacy and net worth. They concluded that financial knowledge increases the likelihood of investing in the stock exchange, allowing individuals to benefit from the equity premium. Morrin et al. [14] analyzed stock market behavior by investigating the effect of fund assortment on asset allocation choices. They found out that more knowledgeable investors were less likely to change their portfolio composition in response to changes in fund assortment. They further established that individuals with lower levels of debt literacy tended to conduct high-cost transactions; the less financially literate were either unable to judge their debt position or reported excessive debt loads.

Moak et al. [15] found out that traditional financial theories assume that individuals draw utility from their own consumption. However, many researchers are mindful that the behavior of investors comparing themselves with others around them, depicted as keeping up with the Joneses may drive individual's investment decisions. Lauterbach and Reisman [16] argued that investors prefer domestic assets to mimic the economic fortunes and welfare of their neighbors, countrymen and social preference groups. Demarzo et al. [17] developed a model in which even rational and risk averse agents may overinvest in risky technology stock. With the model, the authors demonstrate that an indirect utility with keeping up with the Joneses properties can induce herding and hence promote investment bubble.

Abu et al. [18] established that savings and investments are co-integrated. Feldstein and Horioka [19] also established that domestic savings and investments are highly correlated. They further argued that when households savings are low, there will be very little investment in securities market, while when it is high; there will be an increase in investment in the securities market.

\section{Research Objectives}

The general objective of the study was to investigate the determinants of bear market performance at the Nairobi Securities Exchange in Kenya.

\section{Specific Objectives}

The following were the specific objectives in line with the research problem: To determine the influence of transaction cost on bear market performance at the Nairobi Securities Exchange in Kenya; To establish the influence of mobilization of resources by retail investors on bear market performance at the Nairobi Securities Exchange in Kenya; To establish the influence of financial literacy on bear market performance at the Nairobi Securities Exchange in Kenya; To establish the influence of cultural values on bear market performance at the Nairobi Securities Exchange in Kenya.

\section{Research Questions}

The following were the research questions that were used to achieve the research objectives: Does transaction cost determine bear market performance at the Nairobi Securities Exchange in Kenya? Does mobilization of resources by retail investors determine bear market performance at the Nairobi Securities Exchange in Kenya? Does financial literacy determine bear market performance at the Nairobi Securities Exchange in Kenya? Do cultural values determine bear market performance at the Nairobi Securities Exchange in Kenya?

\section{Research Hypotheses}

This study was guided by the following research hypotheses:

$\mathrm{H}_{0}$ 1: Transaction cost has no significant influence on bear market performance at the Nairobi Securities Exchange in Kenya.

$\mathrm{H}_{0}$ 2: Mobilization of resources by retail investors has no significant influence on bear market performance at the Nairobi Securities Exchange in Kenya.

$\mathrm{H}_{0} 3$ : Financial literacy has no significant influence on bear market performance at the Nairobi Securities Exchange in Kenya.

$\mathrm{H}_{0}$ 4: Cultural values have no significant influence on bear market performance at the Nairobi Securities Exchange in Kenya.

\section{Conceptual Framework}

The variables that were investigated consisted of; transaction cost, mobilization of resources by retail investors, financial literacy, and cultural values. The variables are relevant in the Kenyan situation and data for their analysis could easily be collected. The independent variables which were investigated consisted of: transaction cost, mobilization of resources by retail investors, financial literacy and cultural values. The dependent variable for the study was bear market performance. All the variables had manifest variables which were used in administering questionnaires to retail investors. 

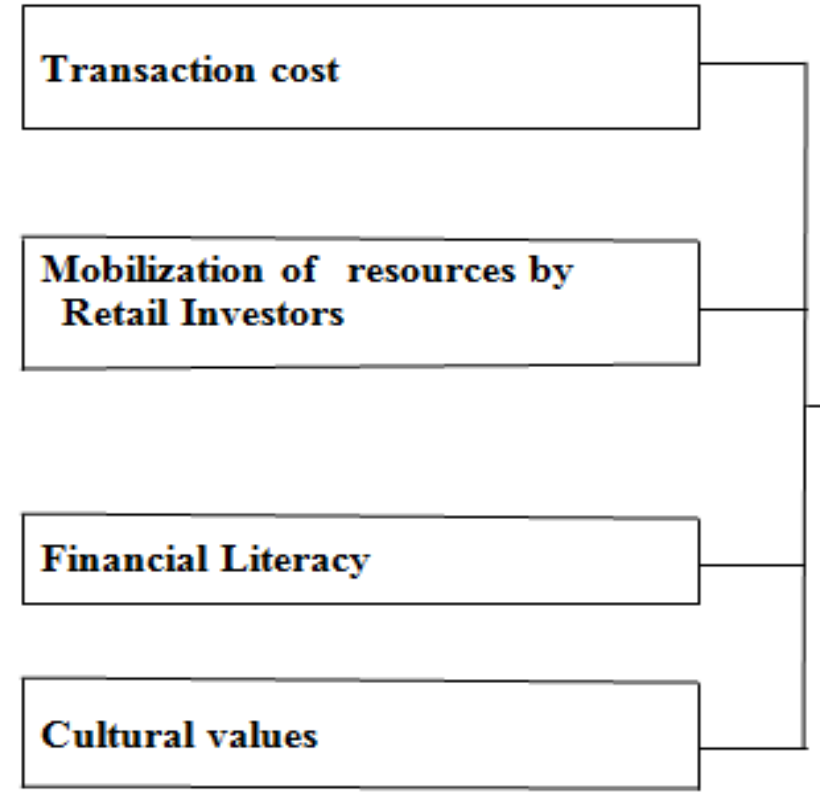

Independent Variables

\section{Bear market Performance}

\section{Dependent Variable}

Figure 1. Conceptual Framework

\section{Methods}

In order to perform statistical tests, the study used mixed research design, namely; quantitative and qualitative approach to analyze the determinants of bear market performance. Specifically, this research used cross-sectional survey method to conduct the study. The study relied on findings from questionnaires distributed through five purposively sampled stock brokers who are registered to trade at the Nairobi Securities Exchange. One hundred questionnaires were dropped in each stock brokerage firm and were filled by retail investors doing business through stock brokerage firms. The sampling technique which was adopted for the study was purposive in that there are stock brokerage firms under statutory management which do not conduct frequent business so it was advisable to rely on stock brokerage firms which are not under statutory management. In administering the questionnaires, the study adopted convenient sampling technique since retail investors were accessed as they transacted business in the stock brokers' offices. This was done over a period of 30 days to attain a desired sample size of 500 respondents.

This sample size was then broken down into administering questionnaires to 200 female retail investors and 300 male retail investors as a representative of the original investors in each category.

\section{Model Specification}

A multiple regression analysis was preferred:

$$
\mathrm{Y}=\beta_{0}+\beta_{1} \mathrm{COST}+\beta_{2} \mathrm{RES}+\beta_{3} \mathrm{LIT}+\beta_{4} \mathrm{CUL}+\varepsilon
$$

Where:

$$
\mathrm{Y}=\text { represents bear market performance }
$$

\section{$\beta_{0=}$ Constant term}

$\beta_{1} \operatorname{COST}=$ Sensitivity of bear market performance to transaction cost.

$\beta_{2}$ RES $=$ Sensitivity of bear market performance to mobilization of resources by retail investors.

$\beta_{3}$ LIT $=$ Sensitivity of bear market performance to Financial literacy.

$\beta_{4} \mathrm{CUL}=$ Sensitivity of bear market performance to cultural values.

$\varepsilon=$ Disturbance term with an expected value of zero.

\section{Results and Discussions}

\section{Summary Model for the Determinants of Bear Market Performance}

The standardized factor scores resulting from factor analysis and used in the preceding section for hypothesis testing were cumulated for each study variable and their means computed to obtain composite variable scores. The composite variable scores were then used to conduct summary correlation and regression analyses which are thus discussed in this section.

\section{Correlation between Determinants and Bear Market Performance}

The variable mean scores were used to compute the Pearson's Product Moment Correlation coefficient to determine the magnitude and direction of the relationships between the independent (determinants of bear market performance) and dependent (bear market performance) variables. The correlation results were as shown in Table 1 . 
Table 1. Correlation Matrix for Determinants and Bear Market Performance

\begin{tabular}{|c|c|c|c|c|c|c|}
\hline & & $\begin{array}{l}\text { Bear Market } \\
\text { performance }\end{array}$ & Transaction Costs & $\begin{array}{l}\text { Mobilization of } \\
\text { resources by retail } \\
\text { investors } \\
\end{array}$ & $\begin{array}{c}\text { Financial } \\
\text { Literacy }\end{array}$ & $\begin{array}{l}\text { Cultural } \\
\text { Values }\end{array}$ \\
\hline \multirow{3}{*}{ Transaction Costs } & Pearson's (r) & $-.241^{* *}$ & 1 & & & \\
\hline & $\mathrm{p}$-value & .000 & & & & \\
\hline & $\mathrm{N}$ & 490 & 490 & & & \\
\hline \multirow{3}{*}{$\begin{array}{l}\text { Mobilization of resources } \\
\text { by retail investors }\end{array}$} & Pearson's (r) & -.039 & $.426^{* *}$ & 1 & & \\
\hline & $\mathrm{p}$-value & .395 & .000 & & & \\
\hline & $\mathrm{N}$ & 490 & 490 & 490 & & \\
\hline \multirow{3}{*}{ Financial Literacy } & Pearson's (r) & $.116^{*}$ & .075 & $.197^{* *}$ & 1 & \\
\hline & $\mathrm{p}$-value & .010 & .098 & .000 & & \\
\hline & $\mathrm{N}$ & 490 & 490 & 490 & 490 & \\
\hline \multirow{3}{*}{ Cultural Values } & Pearson's (r) & -.086 & -.027 & .001 & -.061 & 1 \\
\hline & p-value & .057 & .555 & .975 & .176 & \\
\hline & $\mathrm{N}$ & 490 & 490 & 490 & 490 & 490 \\
\hline
\end{tabular}

**. Correlation is significant at the 0.01 level (2-tailed).

*. Correlation is significant at the 0.05 level (2-tailed).

As the matrix shows, there were statistically significant correlations between transaction costs and bear market performance $(r=-.241 ; \mathrm{p}=0.000 ; \mathrm{n}=490)$ and financial literacy and bear market performance $(\mathrm{r}=.116 ; \mathrm{p}=0.01 ; \mathrm{n}$ $=490$ ). The negative correlation between transaction cost and bear market performance implied that the more the retail investors perceived transaction costs as determinant of bear market performance, the more likely it was for them to report lower performance in the bear market. On the contrary, the more the retail investors perceived financial literacy as a determinant of bear market performance, the more likely they were to report higher performance in bear market. Nevertheless, the correlations were weak in strength indicating that bear market performance was weakly associated with transaction costs and financial literacy. The relationship between bear market performance and mobilization of resources by retail investors as well as cultural values was largely insignificant.

\section{Summary Regression Model}

The variables' standardized mean scores were used to run a multiple, linear regression analyses with the four determinants of bear market performance as predictors and bear market performance as the response variables using the regression model below:

$$
Y_{i}=\alpha+\beta_{1} C O S T+\beta_{2} R E S+\beta_{3} L I T+\beta_{4} C U L+\varepsilon
$$

Where:

$$
\begin{gathered}
\boldsymbol{Y}_{\boldsymbol{i}}=\text { Bear Market Performance } \\
\boldsymbol{\alpha}=\text { Constant/Intercept; }
\end{gathered}
$$
$\boldsymbol{\beta 1 . . . \beta 4}$ are regression coefficients of the independent variables;
$\boldsymbol{C O S T}=$ Transaction costs;

$\boldsymbol{R E S}=$ Mobilization of resources by retail investors;

$$
\begin{aligned}
& \boldsymbol{L I T}=\text { Financial literacy; } \\
& \boldsymbol{C} \boldsymbol{U} \boldsymbol{L}=\text { Cultural Values and; } \\
& \boldsymbol{\varepsilon}=\text { Error term }
\end{aligned}
$$

When bear market performance was regressed against transaction costs, mobilization of resources by retail investors, financial literacy and cultural values, the ANOVA results indicated that the model was significant $(\rho$ $=0.000$ ), with the independent variables explaining $7.8 \%$ $\left(\mathrm{R}^{2}=0.078\right)$ of the variance in the perceived bear market performance. The ANOVA results were as shown in Table 2.

Table 2. ANOVA Results for the Summary Regression Model

\begin{tabular}{|c|c|c|c|c|c|c|}
\hline \multicolumn{7}{|c|}{ ANOVA $^{\mathrm{a}}$} \\
\hline \multicolumn{2}{|c|}{ Model } & Sum of Squares & df & Mean Square & F & Sig. \\
\hline \multirow{2}{*}{ Regression } & 64.514 & 4 & 16.129 & 11.372 & $.000^{\mathrm{b}}$ \\
\hline & Residual & 687.875 & 485 & 1.418 & & \\
\hline & Total & $\mathbf{7 5 2 . 3 9 0}$ & $\mathbf{4 8 9}$ & & & \\
\hline
\end{tabular}

a. Dependent Variable: Bear Market performance

b. Predictors: (Constant), Cultural Values, Mobilization of resources by retail investors, Financial Literacy, Transaction Costs

The regression model coefficient results for the determinants of bear market performance were as presented in Table 3. 
Table 3. Regression Model Coefficients for the Determinants of Bear Market Performance

\begin{tabular}{|c|c|c|c|c|c|}
\hline \multirow{3}{*}{ Model } & \multicolumn{2}{|c|}{ Coefficients $^{\mathrm{a}}$} & \multirow{3}{*}{$\begin{array}{c}\text { Standardized } \\
\text { Coefficients } \\
\text { Beta }\end{array}$} & \multirow{3}{*}{$\mathbf{t}$} & \multirow{3}{*}{ Sig. } \\
\hline & \multicolumn{2}{|c|}{ Unstandardized Coefficients } & & & \\
\hline & B & Std. Error & & & \\
\hline (Constant) & $-1.055 \mathrm{E}-013$ & .054 & & .000 & 1.000 \\
\hline Transaction Costs & -.253 & .044 & -.276 & -5.746 & .000 \\
\hline Mobilization of resources by retail investors & .054 & .048 & .055 & 1.133 & .258 \\
\hline Financial Literacy & .121 & .044 & .121 & 2.720 & .007 \\
\hline Cultural Values & -.061 & .031 & -.086 & -1.975 & .049 \\
\hline
\end{tabular}

a. Dependent Variable: Bear Market performance

The multivariate correlation and regression analysis of the full model revealed that overall, at $\mathrm{p}<0.05$, transaction costs and cultural values negatively influence bear market performance while financial literacy positively influences bear market performance. However, Mobilization of resources by retail investors did not contribute significantly to bear market performance. Thus, the resulting summary regression model would be:

\section{Bear Market Performance $=-0.253($ COST $)+0.121($ LIT $)$ $-0.061(C U L)$}

\section{Conclusions and Recommendations}

Transaction costs were operationalized as commission by brokerage firms, inflation rate, extent of incorporation of information technology in doing business, agency cost and interest rate on mutual funds. On the other hand, bear market performance comprised fluctuating share prices, declining primary trend, lack of trading activity at the bourse and insolvency and bankruptcy risk of firms. From table 1, the results of the study showed that bear market was weakly associated with transaction costs. From table 3, it showed that transaction cost negatively influences bear market performance. Therefore, based on ANOVA results from table 2 that showed that there were significant relationships between the transaction cost variables and bear market performance variables the first null hypothesis $\left(\mathrm{H}_{0} 1\right)$ which stated that: Transaction cost has no significant influence on bear market performance at the Nairobi Securities Exchange in Kenya was rejected at this point.

The mobilization of resources by retail investors' scale comprised of the items: interest rates on bank loans; levels of dependants; prices of consumable commodities; level of disposable income; taxation of capital gains; level of remittances and; level of per capita income. From table 1, the relationship between bear market performance and mobilization of resources was insignificant. Also, table 3 which involved multivariate correlation and regression analysis revealed that mobilization of resources by retail investors did not contribute significantly to bear market performance. The second null hypothesis $\left(\mathrm{H}_{0} 2\right)$ which stated that: Mobilization of resources by retail investors has no significant influence on bear market performance at the
Nairobi Securities Exchange in Kenya was accepted.

Financial literacy was measured on a 4-item measurement scale: Level of literacy in the country, dissemination of financial information by capital markets at the bourse; availability of financial information at the brokers' outlets and investment promotion incentives. The first factor was labeled "Investment knowledge" and (level of literacy in the country and dissemination of financial information by capital markets at the bourse) while the second factor was named "Financial knowledge" (Investment promotion incentives and availability of financial information at the brokers' outlets). Results revealed that only investment knowledge had a statistically significant and positive relationship with declining primary trend. This means that retail investors who perceived investment knowledge as a determinant of bear market performance were more likely to report that declining primary trend affected bear market performance. From table 1 , it was confirmed that bear market was weakly associated with financial literacy, while from table 3 it was confirmed that financial literacy positively influences bear market performance. Therefore, the third null hypothesis $\left(\mathrm{H}_{0} 3\right)$ which stated that: Financial literacy has no significant influence on bear market performance at the Nairobi Securities Exchange in Kenya was rejected.

The measurement scale for cultural values comprised four items: keeping up with the Joneses, family influence, peer influence, religious Influence and tradition and time for rewarding employees. From table 4.1, it was confirmed that the relationship between bear market performance and cultural values was insignificant. However, from table 3, it was confirmed that cultural values negatively influence bear market performance. The fourth null hypothesis $\left(\mathrm{H}_{0} 4\right)$ which stated that: Cultural values have no significant influence on bear market performance at the Nairobi Securities Exchange in Kenya was rejected.

\section{Conclusions}

Based on the findings of this study, it is concluded that various manifest variables of transaction cost as conceptualized by this study influence bear market performance on the NSE. However, the variable extent of incorporation of information technology in doing business has no relationship with bear market performance with 
respect to lack of trading activity at the bourse. These manifest variables on the other hand define two main latent factors, which this study has labeled; "brokerage costs" and "agency costs". Whereas brokerage costs negatively influence bear market performance variables conceptualized risks of firm dissolution and declining primary trend, agency cost was found to be a negative correlate of declining primary trend, but its relationship with risks of firm dissolution remained insignificant. Generally, it is concluded that brokerage costs negatively influence firm dissolution risks while declining primary trend as a measure of bear market performance is negatively affected by both brokerage costs and agency costs.

The study concludes that all the manifest variables of the main construct; "mobilization of resources by retail investors" (interest rates on bank loans; levels of dependants; prices of consumable commodities; level of disposable income; taxation of capital gains; level of remittances and; level of per capita income) have influence of varying degrees on bear market performance. The 7 manifest variables define three main latent variables named in this study "Household resource dynamics", "National wealth" and "Taxation of capital gains". Taxation of capital gains is a positive correlate of bear market performance with respect to risks of firm dissolution and declining primary trend. National wealth negatively correlates with declining primary trend. The relationship between household resource dynamics factor of the resource mobilization scale and both factors of bear market performance is concluded to be largely insignificant. Thus, mobilization of resources by retail investors when looked at from the perspective of National wealth" and taxation of capital gains is a determinant of bear market performance.

Financial literacy, when measured considered as a multi-dimensional construct on a 4-item measurement scale (level of literacy in the country, dissemination of financial information by capital markets at the bourse; availability of financial information at the brokers' outlets and investment promotion incentives) has a relationship with bear market performance in different pathways. Deviant relationships are however exhibited between dissemination of financial information by capital markets at the bourse and consistently declining primary trend, and availability of financial information at the brokers' outlets and insolvency and bankruptcy risk of firms trading at the bourse. This study concludes that financial literacy scale has two main latent variables named as "Investment knowledge" and (level of literacy in the country and dissemination of financial information by capital markets at the bourse) and "Financial knowledge" (Investment promotion incentives and availability of financial information at the brokers' outlets). Only investment knowledge had a statistically significant and positive relationship with declining primary trend. Investment knowledge positively influences bear market performance in relation to retail investors' perceived effect of declining primary trend, while financial knowledge does not contribute significantly to perceived effects of declining primary tendon bear market performance.

It is concluded that all the dimensions of cultural values as measured by this study (keeping up with the Joneses, family influence, peer influence, religious influence and tradition and time for rewarding employees) have a relationship with constituent bear market performance variables except the relationship between family influence and consistently declining primary trend and tradition and time for rewarding employees and consistently declining primary trend. The study further concludes that two main latent variables labeled in the study as "Individual cultural values" (Family influence, Peer influence and Religious influence) and "Corporate cultural values" (Tradition and time for rewarding employees and Keeping up with the Joneses a determinant)are defined by the manifest variables as bracketed. Individual cultural values is a negative correlate of firm dissolution risks while corporate cultural values is a positive correlate of declining primary trend, but has a significant negative relationship with farm dissolution risks.

\section{Recommendations}

Investors need to have an idea about the determinants of bear market and how it affects performance of share prices at the bourse. Most of the variables that determine bear market performance are normal occurrence of cycles in economic performance of a country such as inflation. Investors should therefore not be in a haste to dispose of their investment in a consistent bear market but they should hold on to their investment since markets always corrects themselves if they are efficient.

Policy formulators and implementers such as the Capital Markets Authorities should take it upon themselves to educate investors on the occurrence of bear market as a normal market situation and that after sometime an efficient market will always change from a bear market to a bull market depending on prevailing economic situation. They should also encourage investors to purchase stocks during a bear market since this action will in the long run create demand for stock in the secondary market and therefore alter the situation.

\section{Suggestions for Further Research}

Most of the variables studied: transaction cost, mobilization of resources by retail investors, financial literacy and cultural values to some extent have an influence on the performance of bear market. The study therefore suggests that other variables other than the ones studied should be studied so as to establish their influence on bear market performance. Further research should also be carried out on the general effect of economic cycles on bear market performance so as to enhance the knowledge on bear market performance and improve on the literature. Though the study established that other sub-variables within the major variables did not have an influence on bear 
market performance, further research should be done in such areas so as to ascertain their influence.

\section{REFERENCES}

[1] Niederhoffer, V. \& Osborne, M. (1966). Market Making and reversal on the Stock Exchanges. Journal of the American Statistical Association, 61(316), 897 - 916.

[2] Robert, R. \& Prechter, J. (2009). Does the Wave Principle Subsume all Valid Technical Chart Patterns? Journal of Technical Analysis, 66(1), 27 - 50.

[3] Richard, R. Charles, C. \& Paul, S. (2009). Dow Theory Unplugged: Charles Dow's Original Editorials and their Relevance Today ( $2^{\text {nd }}$ ed.). New York, NY: Wasendorf \& Associates Inc.

[4] Chordia, M. (2007). Trading Activity and Expected Stock Returns. Journal of Financial Economics, 59(3), 3- 32.

[5] Ramos, K. (2007). Mean Reversion in Stock Prices: Evidence and Implications. Journal of Financial Economics, 22(1), $26-59$.

[6] Dukes, T., Bowlin, M. \& McDonald, F. (2011). A non Parametric Investigation of Duration Dependence in the American Business Cycles. Journal of Political Economy, 98(3), $596-616$.

[7] Chauvet, M. \& Potter, S. (2008). Coincident and Leading Indicators of the Stock market. Journal of Empirical Finance, $7(1), 87-111$.

[8] Lesmond, D., Oglen, J. \& Trzcinka, C. (2011). A new estimate of Transaction costs. Review of Financial Studies, $12,1113-1141$.
[9] Amy, K., Lawrence, E. \& Michaels, P. (2012). Corporate Bond Market Transaction costs and Transparency. The Journal of Finance, 62(4), 1421 - 1451.

[10] Rogers, R. (2008). Relationship between Regression and Volatility tests of Market Efficiency. Econometrica, 49(2), $555-574$.

[11] Durham, V. (2010). Sacrifice Ratios and Monetary Policy Credibility. Finance and Economics Journal, 47(2), 423 452.

[12] Maxx, K. (2011). Economic and Philosophic manuscripts. Economy and Society Journal, 30(2), 44 - 72.

[13] Maarten, C., Van, R. and Annamaria, L. (2012).Financial Literacy Retirement Planning and household wealth. The Economic Journal, 122(560), 449 - 478.

[14] Morrin, M., Susan, B. \& Jeffrey, I. (2011). Saving for Retirement: The Effects of Fund Assortment Size and Investor Knowledge on asset allocation strategies. Journal of Consumer Affairs, 42(5), 206 - 222.

[15] Moak, S., Siregar, D. \& Qun, W. (2012). Effect of Keeping Up with the Joneses preference on investment behavior. Journal of Financial Economics, 21(50), 825 - 852.

[16] Lauterbach, B. \& Reisman, H. (2011). Keeping up with the Joneses and the Home bias. European Financial Management, 19 (26), 225 - 234.

[17] DeMarzo, K. \& Kremer, J. (2010). Technological Innovation and real Investment Booms and Busts. Journal of Financial Economics, 21 (4), 735 - 754.

[18] Abu, M., Mohamed, T. \& Abdullah, H. (2010). Savings and Investments in South Asia. Journal of Savings and Development, 21(3), 261 - 274.

[19] Horioka, J. \& Feldstein (2008). A Long Memory Property of Stock Returns and a new Model. Journal of Empirical Finance, 1(2), 83 - 106. 